UK research councils

\section{Cake-cutting done}

THE science and medical research councils are the chief beneficiaries of the extra $\mathfrak{E} 14$ million the British government has made available for the coming financial year. The allocation of the extra funds was to be disclosed in the annual "forward look" of the Advisory Board for the Research Councils (ABRC), whose publication has been brought forward to help the Secretary of State for Education and Science to defend himself against his critics in the House of Commons who are complaining at the way the extra science money has been quarried from the budget for students' maintenance grants.

The ABRC document has something of the character of a ritual dance. To begin with, it records its own estimate of the funds that would be needed to take advantage of new opportunities for research that have been presented in the past year, reckoning that these would cost an extra $£ 35.5$ million in 1985-86. On the other hand, $A B R C$ says elsewhere in the same document, the extra $£ 14$ million for next year (which is $£ 16$ million if account is taken of the way in which the government compensates the research councils for pay settlements) "will allow many important research projects" to continue that would otherwise have been allowed to lapse.

Much of the extra money for the coming financial year will be spent on what is called "restructuring", a euphemism for persuading researchers to retire early when the institutes at which they work are closed. ABRC had asked for 19 million in 1984-85, but the government has allowed $£ 6$ million (reducing to $£ 5$ million and $£ 3$ million in the two succeeding years).

Under the allocation scheme proposed by ABRC and accepted by the government, the medical and science research councils will benefit chiefly because they would otherwise have been "taxed" so as to free funds for other research councils having to close establishments. In reality, the Science and Engineering Research Council (SERC) will do best out of the new deal; its budget is due to increase from $£ 279$ million this year to $£ 299.1$ million (at 1984 prices) next year and to $£ 306$ million and $£ 311$ million in each of the two succeeding years. The Medical Research Council's budget will increase by $£ 6$ million between this year and next and then by a further $£ 5$ million in the two succeeding years. The budget of the Agricultural and Food Research Council is due to decline gently from next year, as forecast in previous forward looks.

Among the innovations of the new British science budget is a device whereby ABRC will keep up its sleeve (in the year beginning in April 1986) a contingency reserve, initially $£ 6$ million but doubling in the following year. At the same time, the cost of providing a secretariat for ABRC and of carrying out a few rudimentary science policy studies will cease to be laundered through the budget of the Economic and Social Research Council, but will be identified separately.

The overall effect of the new proposals will on balance be neutral. Sir David Phillips, chairman of ABRC, says in the documents to be published this week that the extra money "will restore level funding". By the same test, the new arrangements will not make it possible to do much that is new. Nor will they help SERC and the British government to decide whether or not to pull out of CERN, the next big row in the research councils' calendar.

\section{EPA moves}

\section{Washington}

President Reagan has named Lee $M$. Thomas to succeed William D. Ruckelshaus as administrator of the US Environmental Protection Agency (EPA).

Ruckelshaus, whose resignation takes effect on 5 January, has earned widespread praise for restoring morale at EPA following the scandals during the term of office of Anne M. Burford. Only one of the 20 political appointees who ran EPA under Burford remains today, the remainder having resigned, been fired or convicted of

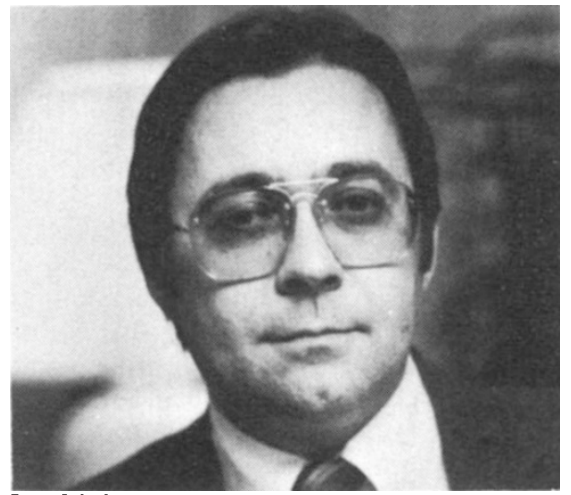

Lee M. Thomas

perjury. Thomas, a career bureaucrat, has been assistant administrator in charge of the "superfund" toxic waste programme.

Thomas, whose appointment has to be ratified by the Senate, is a political independent who seems to be acceptable to environmental groups. But with the President under strong pressure to find budget cuts, EPA must be a possible target. Richard Ayers, senior staff attorney with the Natural Resources Defense Council, wonders whether Thomas will carry the political weight to defend the agency, whose operating budget, at $\$ 1,200$ million, is still less than it was in 1980 in nominal dollars. Earlier this year, Thomas told the House of Representatives that a proposed budget increase for the superfund programme, tied to a new timetable, would actually slow down the superfund work.

Tim Beardsley
Natural environment UK council counts pennies

THE British Natural Environment Research Council (NERC) acknowledged last week that it can no longer adequately support those who look to it for research funds. According to $\mathrm{Mr} \mathrm{Hugh}$ Fish, the new chairman, NERC has been squeezed by the general decline of government support and by the unwillingness of government departments to commission research. Speaking at the launch of NERC's annual report, Mr Fish said the council would have to become more selective, and promised a "corporate plan" early in 1985 that might identify areas of research to be temporarily or permanently abandoned.

Anticipating the forthcoming corporate plan, Mr Fish thought there would be a bright future for deep seismic sounding, where grant applications are buoyant. By contrast, remote sensing has been disappointing. Dr John Bowman, NERC's secretary, said last week that the process of peer review may not be the most effective, but that NERC's activity in this field may be more pointed because of plans to work more closely with the Science and Engineering Research Council.

NERC's constitutional difficulty is the large proportion of its budget committed to its own institutions, which took twothirds of what the council had to spend last year. By comparison, support for academic research last year amounted only to 17 per cent of what NERC spent. Mr Fish would like to see this proportion doubled, but he did not say by when.

As things are, in its support of terrestrial and aquatic life sciences, and of environmental studies in the physical sciences, NERC was able to meet less than a quarter by value of the grants applied for. Its report for last year records regret at not being able to support work in remote sensing of the sea surface, vegetation and soil hydrology and the development of geological ion probes. In short, NERC cuts the figure of a harassed housewife on a restricted housekeeping budget.

So why, for example, spend $£ 10$ million on support of the British Antarctic Survey? Mr Fish is glad that the British government has given this field priority and would like "similar treatment for other areas".

In one respect, however, NERC has been able to break new ground. The council has taken steps to market its services as a research organization willing to take on commissions, and has set up an office in Brussels to ensure that its constituent laboratories derive as much benefit as possible from the European Commission's budget. The report even offers the services of its Brussels office to British universities that might wish to make use of them - but at a fee.

Philip Campbell 